\title{
ROOFLESS CAVES, A POLYGENETIC STATUS OF CAVE DEVELOPMENT WITH SPECIAL REFERENCES TO CAVE REGIONS IN THE EASTERN CALCAREOUS ALPS IN SALZBURG AND CENTRAL ALPS, AUSTRIA
}

\section{"BREZSTROPE" JAME KOT STOPNJA V RAZVOJU JAM NA PRIMERU VZHODNIH APNENIŠKIH ALP NA SALZBURŠKEM IN CENTRALNIH ALP (AVSTRIJA)}

KARL MAIS $^{1}$

\footnotetext{
${ }^{1}$ Naturhistorisches museum in Wien, Karst - und Höhlenkundliche Abteilung, Spaläologisches Dokumentationszentrum, Museumplatz 1/10/1, AT-1070 WIEN, AUSTRIA,

E-mail: speleo.austria@netway.at
} 
UDK: 551.44(436)

\section{Karl Mais: "Brezstrope" jame kot stopnja v razvoju jam na primeru Vzhodnih Apneniških Alp na} Salzburškem in Centralnih Alp (Avstrija)

O pojavu brezstropih jam je že zgodaj poročal B. Dawkins (1874). F. Kraus je ugotovil, da so take jame stopnja v razvoju od normalnih jam do vrtač in sotesk, iz katerih kasneje nastanejo normalne doline. Kot primer navaja Rakov Škocjan in še posebej jamo Lončarevec pri Postojni. V Alpah so pleistocenski ledeniki zniževali površje in odprle so se jame. Ponekod je danes veliko kratkih jam - ostankov nekdanjih sistemov. Značilne so za "nivo jamskih razvalin" (Höhlenruinen-Nivo) na planotah, kot so Steinernes Meer, Hagengebirge, Tennengebirge, v višinah 2000 - 2300 m. Avtor podrobneje obravnava primere iz salzburških Apneniških Alp, področji Hennenkopf in Rotwandl v pogorju Steinernes Meer, Sondkar v pogorju Tennengebirge in Hochtor v Centralnih Alpah (Visoke Ture).

Ključne besede: kraška morfologija, speleogeneza, brezstropa jama, Avstrija, Vzhodne Apneniške Alpe, Centralne Alpe.

\section{Abstract}

UDC: 551.44(436)

Karl Mais: Roofless Caves, a polygenetic status of cave development with special references to cave regions in the Eastern Calcareous Alps in Salzburg and Central Alps , Austria

The phenomenon of roofless caves was reported early by Boyd Dawkins (1874). Franz Kraus found that roof collapses are the first steps in the development from a normal subterranean cave to dolines and to a gorge and to normal valley. As an example he showed Rakov Škocjan and specially "Lončarevec Cave" near Postojna. Karst in alpine regions is often dominated by glacier erosion. The ice flow of Pleistocene glaciers carved the plateau surfaces. Thus cave systems opened. In some areas there are a lot of short caves as parts of a former cave system. They characterise the "cave-ruin-niveau" (Höhlenruinen-Niveau) on plateaus such as Steinernes Meer, Hagengebirge, Tennengebirge, in an altitude of 2000-2300m. Special reference is given to the Salzburg Calcareous Alps, including Hennenkopf and the Rotwandl region in the massif of Steinernes Meer, the region of Sandkar in the Tennengebirge and of Hochtor in the Central Alps (Hohe Tauern).

Key words: karst morphology, speleogenesis, roofless cave, Austria, Eastern Calcareous Alps, Central Alps. 


\section{Looking back into literature}

The phenomenon of denudation of karst surfaces, including roofless caves, was reported early, for instance by Boyd DAWKINS. He noticed that cave passages collapse and generate valleys in Devonian formations of England. Also Franz KRAUS found out in his fieldwork that progressive
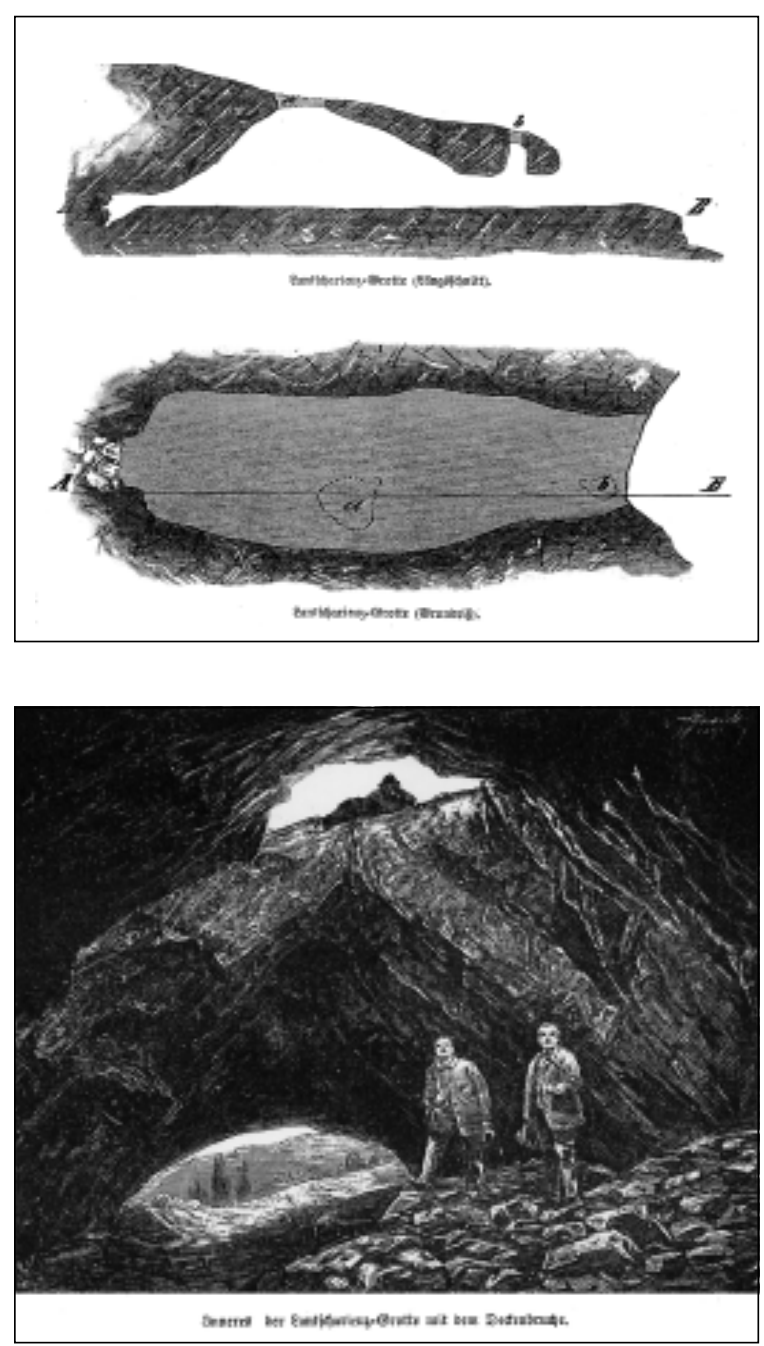

Fig. 1: Example of a cave getting roofless, used by Franz. KRAUS 1894 in his book „Höhlenkunde“ (Cave science): Lončarevec cave near Veliki Otok with roofwindows in the thin roof. Maps from page 73, the illustration, from page 74, a wood engraving after a photo by Šeber (Postojna). roof collapses are the initial steps in the development from a cave in its normal subterranean state first to line of roof windows, further on to a series of dolines with cave remnants and consequently to a gorge or valley.

These forms at first have steep walls, later they flatten more and more to a valley with gentle slopes. KRAUS described Rakov Škocjan as the result of such a sequence of events, as well as the valley of the Reka river going into Škocjanske Jame, with their different sections of tunnels, natural bridges and valley parts. He also pointed out that both surface and subsurface features cause roofless caves. The roofs of caves become thinner and thinner especially by surface denudation, so that they eventually collapse. As an example he presented "Lončarevec Cave" (Potters Cave) near Veliki Otok in the Postojna region. The roof of this cave thinned in parts to 50 or $40 \mathrm{~cm}$. Rocks along cracks in the roof broke down and formed two roof windows. KRAUS (1894: 73-75, 114) illustrated these special features in a horizontal and vertical view (Fig. 1) and also by photographs.

KRAUS wrote that cave fillings on karstic surface, furrows and valleys are remnants of caves in regions with a high denudation rate in the course of time (1894: 203). He showed two types of roofless caves. 
The first type became roofless by collapsed galleries, by fissures upwards to the surface, as shown in his figures (1894: 116 and 117). The second type became roofless especially by surface denudation and following roof-fissuring (Lončarevec Cave).

KRAUS only used examples for roofless caves from the classical Karst, none from the alpine regions in Austria.

\section{Roofless caves in the alpine regions of Austria}

\section{The Northern Limestone Alps in Salzburg}

Roofless caves have scarcely been noticed in Austria, especially because short caves are often widely filled by sediments or collapsed rubble, and cave relicts mostly do not seem to be important enough to be included in the cave register. Register numbers are only given to objects of $5 \mathrm{~m}$ and more. Therefore short caves and fully filled caves are mostly ignored. Just in some cases cave remnants are accepted for the register, not directly as caves, but as parts of a cave ruin zone.

In this survey we will give examples from the Northern Calcareous Alps in Salzburg (Salzburger Kalkalpen), especially from the Steinernes Meer (Hennenkopf- and Rotwandl-region), Hochkönig, Hagengebirge and Tennengebirge, and from the central alpine part of Hohe Tauern, such as the Hochtor-region; see Fig. 2.

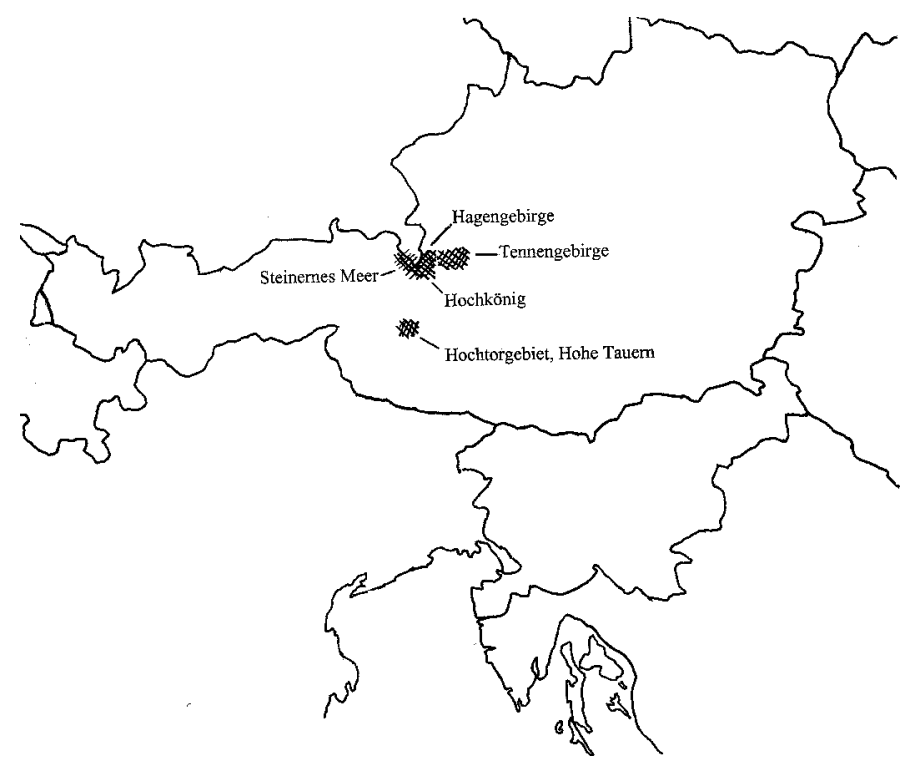

Fig. 2: Region of the examples of roofless caves in the Calcareous Alps of Salzburg (Salzburger Kalkalpen; Steinernes Meer, Hochkönig, Hagengebirge and Tennengebirge) and Central Alps (Hochtor-region, Hohe Tauern). 
The Salzburg Calcareous Alps (Salzburger Kalkalpen) with their plateaux, mostly formed by upper triassic Dachstein limestone, are rich in caves. Great plateaux are present in the Tennengebirge, Hagengebirge, Hochkönig and Steinernes Meer. They are divided by deep valleys along tectonic lines, carved by the effects of Pleistocene glaciation. The edges of the plateaux are often incised by local glacier tongues. By these effects caves opened up, seemingly at different levels. Caves occur at an upper level between about 2200 to about $2000 \mathrm{~m}$, in a middle altitude between 1800 and $1500 \mathrm{~m}$, and at a lower level from approx. $1000 \mathrm{~m}$ to the actual valley level. These zones are called "Höhlenruinenniveau", "Riesenhöhlenniveau" and "Quellhöhlenniveau", but it is better to speak of an upper, middle and lower cave level.

\section{Examples from the Steinernes Meer}

The great limestone massif of the Steinernes Meer, with 552 registered caves (1996), shows different evidence of glaciation with a lot of subsequent karstic forms. In some parts roofless caves are present, they were studied especially in the Hennenkopf and Rotwandl regions.

The Hennenkopf region

During fieldwork near Schindlkopf we investigated morphologic features in the Hennenkopf region and found that the entrances of the Hennenkopfhöhle and Konglomerathöhle are open along a connected joint and bedding plane system. The inclination of the bedding plane was important for the origin of both caves and also became important for the development of the actual surface. Along a joint-system there were obviously cave galleries formerly connectiing the entrance parts of these caves. The joints and gaps on the surface and in the cave roof were the origin of the present short valley, incised by glaciation. The bottom of the valley is covered by fallen rocks. Some parts of the bedding now slip sideways into this valley. Anyhow, there are no remnants of the former cave walls now, but there are flowstone remnants and a bottom canyon of subterranean origin. All these features are altered by surface corrosion.

Nearby, slightly above this location, there are sediments on the actual surface, also gravel with clay, quartzite pebbles, karst ore (Bohnerze) and sometimes calcite elements. These forms, called "Augensteingruben", may also indicate roofless caves. Their surrounding is mostly unobstrusive, but sometimes cave walls can be detected and should be investigated.

The Rotwandl region

In the middle part of the plateau of Steinernes Meer, northerly inclined, there rises mount Rotwandl (2231 m above sea level) with a small plateau about $100 \mathrm{~m}$ above the main plateau. In the slopes and rock walls of the Rotwandl a great number of cave entrances are open, due to glacial erosion. In the more or less flat surrounding (about $2100 \mathrm{~m}$ above sea level) some caves became roofless. Figure 3 shows the situation in the Rotwandl, with about 30 objects (with numbers RW-1 to RW-30) known since 1976. They are described in volume 3 of the "Salzburger Höhlenbuch" (KLAPPACHER \& KNAPCZYK (Ed.) 1977). The longest cave is the "Rotwandhöhle" with a length about $1700 \mathrm{~m}$; the other objects have a length from $150 \mathrm{~m}$ to about $5 \mathrm{~m}$. The average length of the caves is about $2,5 \%$ of the length of the longest one. This relation clearly explains the relic status of the caves. Some of the objects are only ruins with small roofed parts and are therefore not registered as caves. 


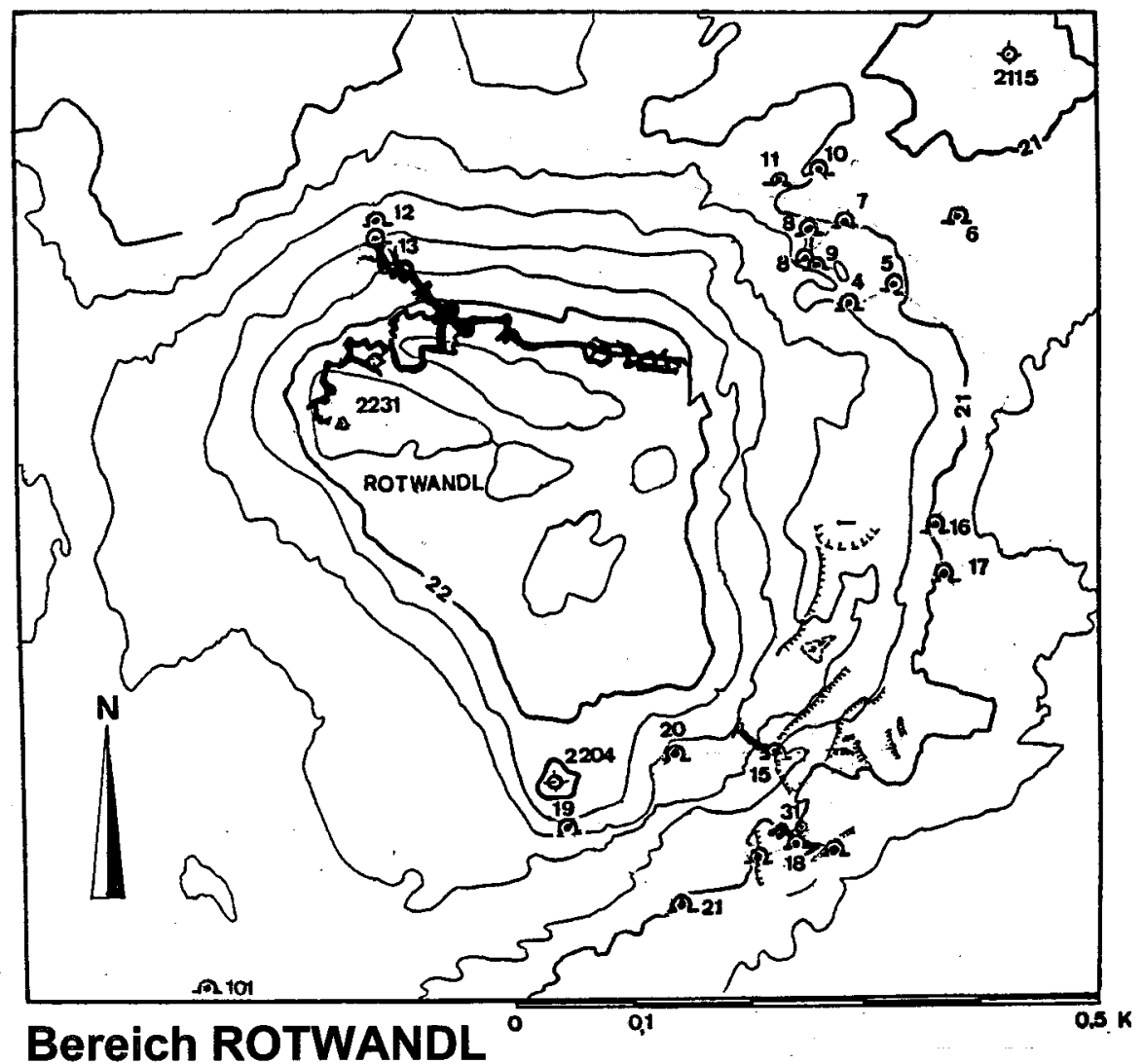

Fig. 3: Caves and cave entrances in Rotwandl-region (Steinernes Meer). The entrance of the "Rotwandlhöhle" (Nr. $13=R W-13)$ is situated in a steep slope. The objects on the east side of Rotwandl are small. Their entrances are opened by glacial erosion and surface denudation; some of them are connected with cave ruins or they are close to roofless caves. The numbers on the map are numbers to mark the objects in the Rotwandl-region (for example RW-4 in the NE part of the map), they are not numbers in the cave-register. After KLAPPACHER \& KNAPCZYK (Ed.) 1977: 222, adapted.

In some cases caves are present as a sequence of roofed and unroofed parts. See for instance the object RW-4 (cave register nr. 1331/052) and its surrounding. RW-4 has a meandering passage of $12 \mathrm{~m}$, continues to the north as an open canyon ending at a rocky bar two meters heigh. On the other side of the bar an unroofed passage connects two roofed parts of several meters. The southern part of RW-4 leads to another sequence of unroofed and roofed parts. It is obvious that the unroofed 


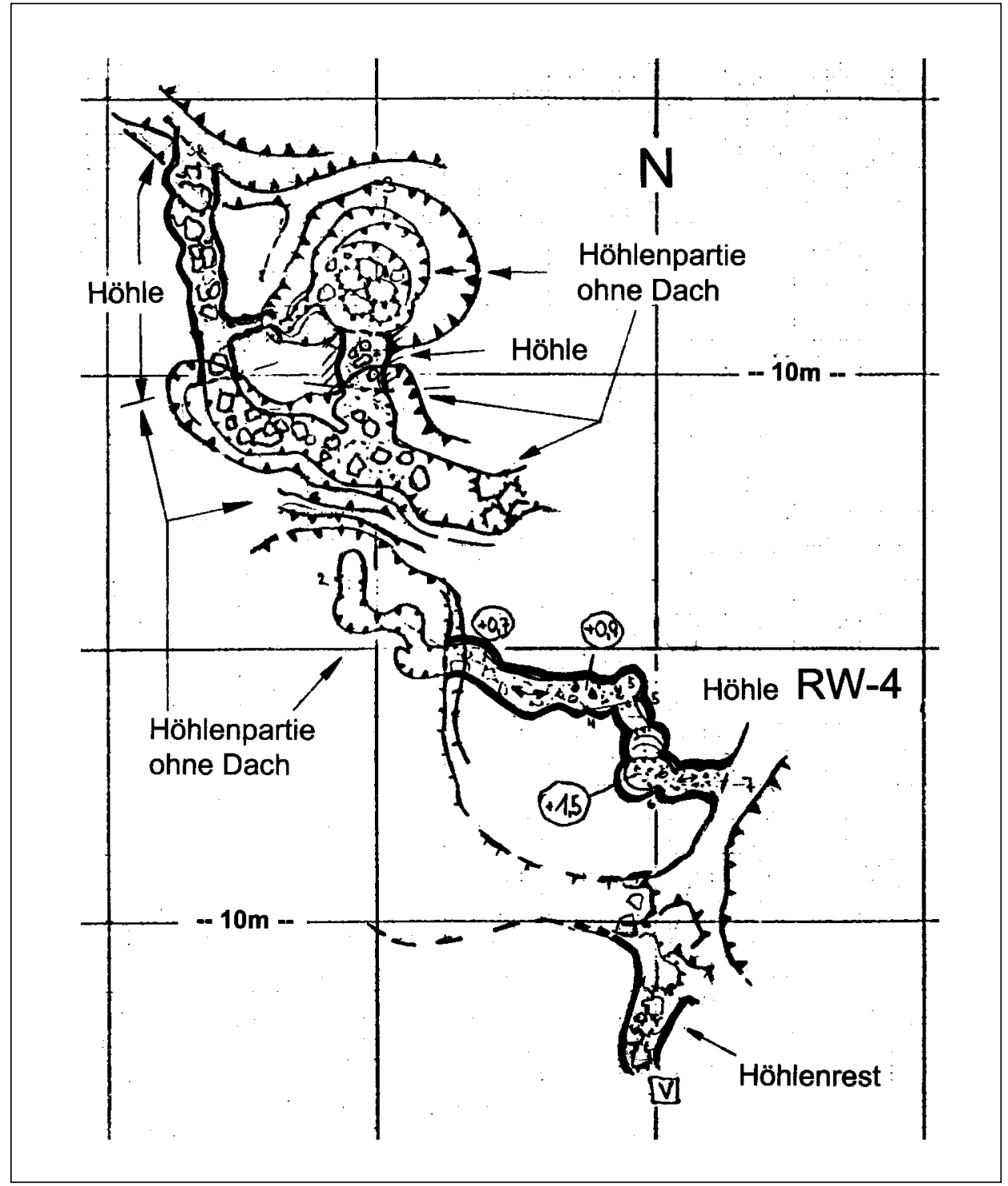

Fig. 4: Cave RW-4 (Rotwandl-region, Steinernes Meer) with roofless connections (Höhlenpartie ohne Dach) to other caves and cave-ruins. Maped by fieldwork, KM-1976.

parts are of subsurface origin and do not represent enlarged „undercut karren“, although they seem to be (BÖGLI 1980: 274-3), because they are in direct contact with real caves in the cave ruin field of the Rotwandl (Fig. 4). 


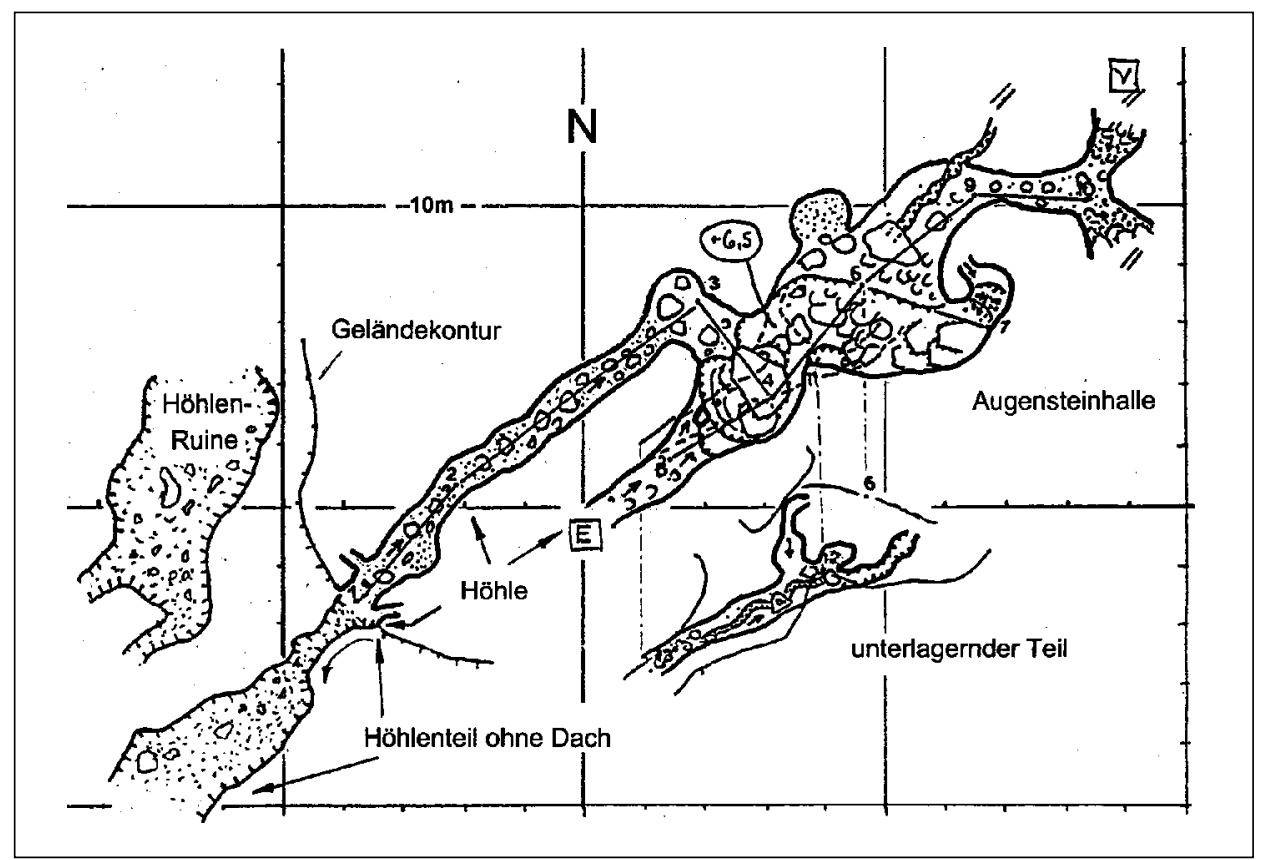

Fig. 5: Cave DR-1 (Rotwandl-region, Steinernes Meer) with direct continuing roofless cave part, close to an other roofless cave (Höhlen-Ruine). Maped by fieldwork, KM-1976.

The roofless sections of RW-4 are partly heavily altered by karstic denudation. For RW-23 this was specially noticed in the Höhlenbuch mentioned above. In another object, with the number DB1 , the cave passage leads directly into a roofless part. Closely to the west there is another completely roofless cave-ruin, only detectable by its contour and a special cave-like sediment (Fig. 5).

Depressions with ground sediments of clay, gravel, flowstone and dripstone particles are also present, for instance in front of the cave RW-18 (1331/103). Another formation without any connection to a cave is more than $30 \mathrm{~m}$ long and $15 \mathrm{~m}$ wide, well outlined and showing shafts on the rocky base. Its wallparts are altered, with deep Rillenkarren; in overhanging parts of the wall there are corrosion pockets and also cave-sediments. For most of the year this depression is filled with snow.

\section{Examples from Hochkönig and Hagengebirge}

The karstmassif of the Hochkönig carries the last active plateau glacier in the Salzburger Kalkalpen. Caves are rare. Pieces of dripstone, however, are frequent. In 1951 GOLDBERGER described cave remnants and relics of heavy flowstone, dripstone formation on the walls and figures. Later he published some other papers about karst and glacial denudation of the Hochkönig; a survey of his work as well as further literature is given in volume 3 of the "Salzburger Höhlenbuch".

In the wide plateau of the Hagengebirge the situation is similar. On the well karstified surface formed by glaciers there is a great number of caves opened by glacial erosion. Many of them are 
cave-ruins - about $2000 \mathrm{~m}$ above sea level -, sometimes only characterized by flowstones. Some caves are close to the surface with only some tenth of a meter of limestone between cave and the surface above. In the "Schachthöhle westl. d. Lengtalscharte" (1335/17), which is more than $500 \mathrm{~m}$ long, the roof is only 20 to $30 \mathrm{~m}$ thick, and in the „Hagenloch“ $1335 / 18$, more than $400 \mathrm{~m}$ long, it is even thinner. On the karst surface flowstones are frequently found. They are mostly not mapped and documented, likewise cave rudiments and roofless caves. Special studies could be made in the upper parts of the Hagengebirge to investigate the former connections and the development of the cave ruin systems.

\section{Examples from the Tennengebirge}

The Tennengebirge is well known for its large and deep caves, like Eisriesenwelt, Eiskogelhöhle, Berger-Cave-System (30.000 m long, -1.265 m deep), Bretterschacht, Herbsthöhle (-1.029 m deep) etc. They have developed in the depth of the Dachstein limestone. At present about 700 caves (1996: 668) are registered.

The central part of the plateau is more or less flat, inclined like the bedding. During the glaciation periods the plateau glacier eroded the old karst surface more or less and carved out glacier valleys at the plateaux-edges. During their systematic investigations in the central plateau members of the Caving Club of Salzburg found a new great cave system in the "Sandkar", incised by glaciation.

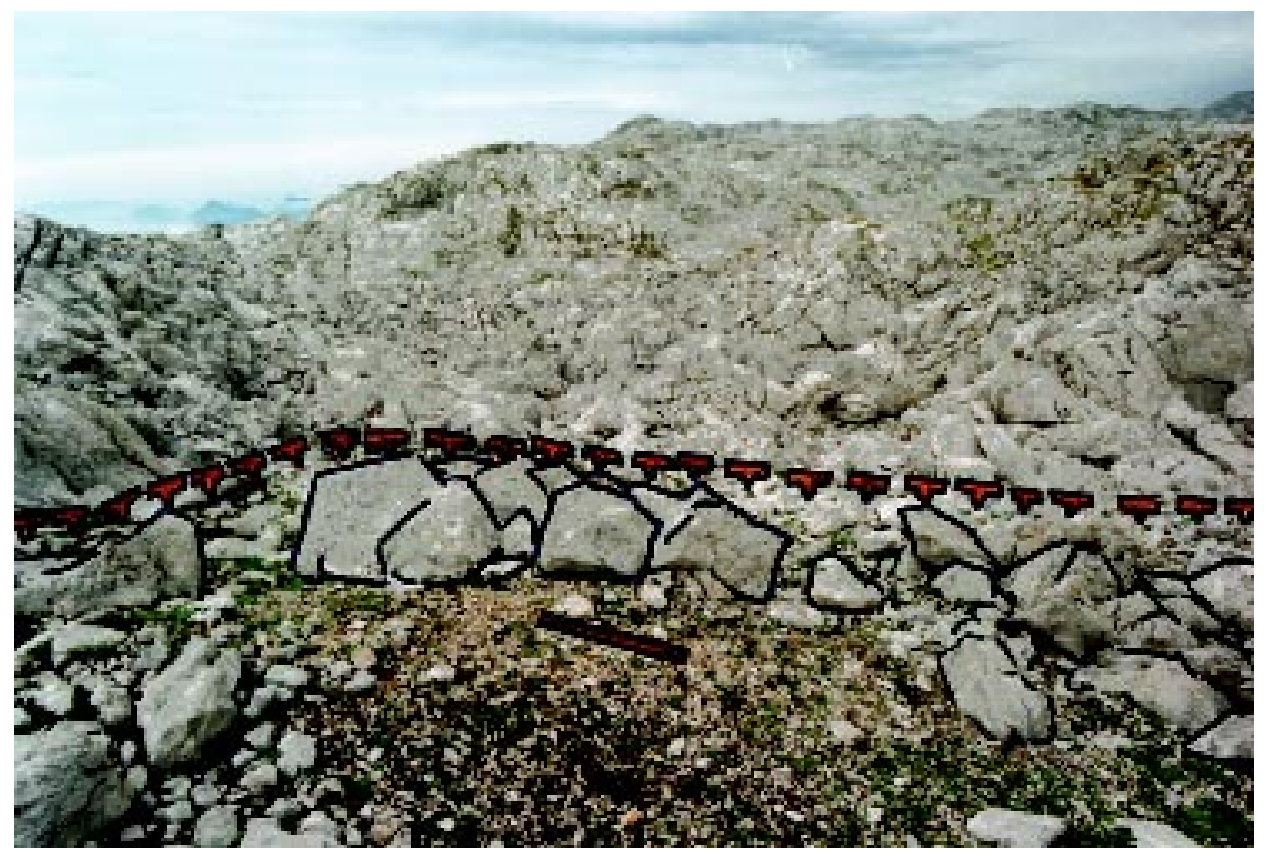

Fig. 6: A former cave in Sandkar-Region of Tennengebirge. The surrounding solid rocks are indicated by a dotted line; arrows to the roofless cave. Boulders inside the line are probably remnans of the cave roof. In front of the boulders a $1 \mathrm{~m}$ long scale. Photo Speldok - Austria 93-TG 5/16-KM. 
Thus the caves „Altherren-Labyrinth“ (1511/550, 13.400m long, -400m deep) and „Thorhöhle“ (1511/153, 1.100m long) are probably remnants of an old interconnected system. This may be assumed, since in the Sandkar (kar meaning glacier valley) close to these two caves there are 26 small cave entrances, representing a cave ruin zone. Above this zone, in higher parts of the plateau, there are places rich with sediment, resembling roofless caves. Clay, karst-ore, calcite and flowstone surrounded by solid rock, probably indicates the former cave (Fig. 6). As to roofless caves, we have only observations, no investigations have been made.

Karst in the Central Alps, Hohe Tauern, Hochtor region; the border Salzburg - Carinthia

In some places of the Central Alps soluble rocks are present, but these karst areas have rarely been investigated so far. North-east of the highest east alpine mountain, the Großglockner (3797 m), lies the region of Hochtor with soluble rocks of middle Triassic (upper Penninic) age. There are outcrops of dolomite and carbonate marble, also evaporite layers (Rauhwacke) with carbonates and gypsum. Rauhwacke layers are mostly very soluble, resulting in a lot of small cavities, but rarely in caves.

The Hochtor region is part of the Hocharn group, in the border zone of Salzburg (S) and Carinthia (K). Between Tauernkopf (2626 m about sea level) and Roßschartenkopf different karstforms have developed. Dolines, shafts, caves, cave ruins and also roofless caves can be found. The karstic surface is covered mostly by weathering debris, so that many karst features are hidden, by snow for long time in the year.

Fieldwork was conducted in the 1980s by Max H. FINK and colleagues, compiled in a field report and published in 1984. At an elevation between 2500 and $2685 \mathrm{~m}$ about 18 notable caves were found. Most of them met the condition for the cave register, and the longest object had a total lengh of 55m. FINK called the surrounding karst surface in the marble zones "bedding step karst" ("Schichttreppenkarst") or cuesta-like karst ("Schichtrippenkarst"). It is often covered with loose, thin elements of weathered bedding. In other places the surface is more or less smooth, flattened by glaciation. Tectonic structures are clearly obvious, open joints and shafts mark these stuctures. Cave parts and interconnected canyons often indicate subsurface drainage.

The Upper and Lower Roßköpflhöhle (2584/ 11 and /12) are good examples. These caves were one cave in former times. In the upper part they show a geat doline with a short cave-tunnel of about $10 \mathrm{~m}$ length, interrupted by a great window in the roof. Further on the roof is absent, the former cave gallery meanders for about 40m downwards into the second „cave“ with a shaft zone and some windows in the roof, followed by the lower, roofed part of the cave, see Fig. 7. The second cave measures up to $55 \mathrm{~m}$. At present the water from the surface from melting snowfields enters the upper part of the cave, flows out into the open canyon and further into the lower cave. The water flow is sometimes covered with gravel and hidden. The cave walls have developed in layers of Rauhwacke; the underlying base is dolomite marble.

Some shallow valleys in this region could also be roofless caves, but they look like surface formations and their karstic origin is hard to trace. Therefore the debris should be removed, to uncover the subsurface forms. Even if there are some roofless caves, the karstification is not restricted to the surface, but caves are obviously connected with deeper cave-levels or joints. The average temperature, as observed in recent years, is higher in the caves than outside (PAVUZA \& KLAPPACHER 1996). 
Karl Mais: Roofless Caves, a polygenetic status of cave development with special references to cave regions in the Eastern...

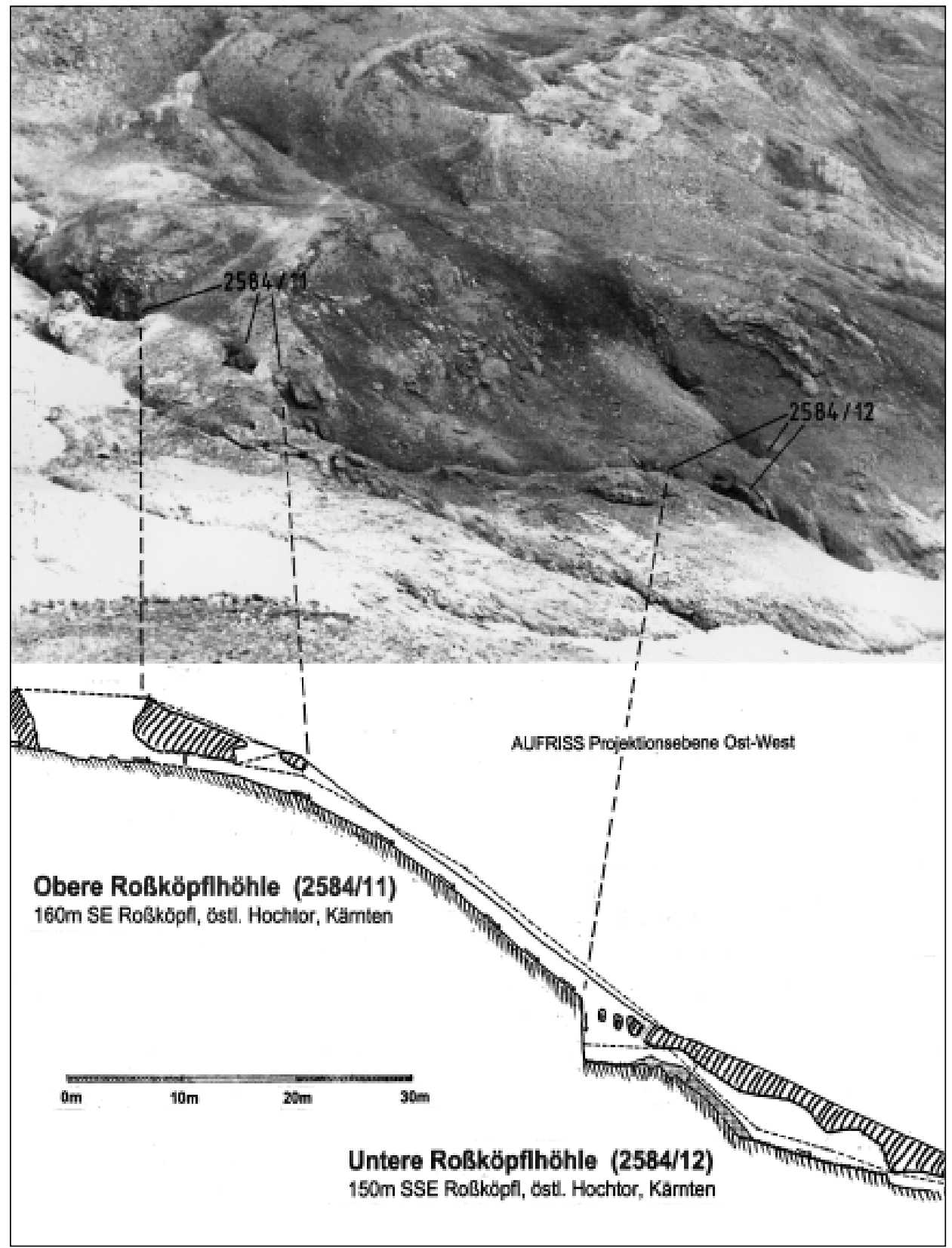

Fig. 7: Obere and Untere Roßköpflhöhle (Hohe Tauern, Carinthia), surface of the Hochtor-region with windows in the roof of both caves, connected by a roofless canyon on part. Photo and sketch after FINK 1984a, adapted. 


\section{CONCLUSION}

In some high Alpine regions of Salzburg roofless caves are situated more or less in "caverelicts-zones", situated mostly above $2000 \mathrm{~m}$ above sea level. There the ice flow of the Pleistocene glaciers incised the plateau surfaces. In consequence cave systems opened up in inclined slopes, as the cave galleries were cut vertically. On a map these open entrances look like dots. On surfaces the cave roofs were eroded. In some local areas nowadays a lot of mostly short caves can be found, representing cut parts of a former cave system, that existed in uneroded slopes before. The horizontally open caves seems to be parts of a subsurface cave system, formerly interconnected and now widely filled up with sediments. In steeper parts of the plateaux, or in mountains rising from a plateau, as well as at the rims of the plateaux, caves were opened up by glacial vertical cuts. These openings are more or less normal cave entrances. Cave entrances filled with sediment may hardly be recognized due to vegetation above. The cave remnants occur at a special level, in the cave ruin zone ("Höhlenruinenzone"). With respect to the mechanisms of opening we may use the term "cave ruin zone" for the surface, not for the caves themselves. They may only be called parts of a "cave-level". If the surface is not eroded in this zone, the caves still exist and have not been ruined.

In the course of eroding or denudating the surface, the cave roof often becomes relatively thin before the cave gets roofless. At this stage the cave roofs sometimes become instable along the tectonic lines, and collapses appear. By fissuring the cave may open up to the surface, as the example of the Schachthöhle w.d. Lengthalschneid shows. By progressive collapses the caves may become roofless, as well as by further surface-erosion. In the most cases the process of getting roofless is hard to determine.

Also quartzite sediments on the karst surface can be sediments of filled caves. Often these sediment pockets are related to old karst surfaces. With respect to roofless caves, they may also be regarded as denuded caves. Some morphological details may support this interpretation . Intensive investigations may answer these questions.

In high Alpine regions glacial surface erosion is more important for the genesis of roofless caves than chemical denudation. Often it is obvious that caves became roofless by glacial erosion, and their fillings show corrosional forms, due to weathering later on. The original cave-qualities of roofless caves are often hard to recognize with altered surfaces.

Caves in Alpine regions became roofless by different denudation processes, more by glacial erosion than by chemical denudation. Tectonic features and the disposal of the bedding planes are important for the polygenetic development of caves and landscape.

\section{REFERENCES}

BÖGLI, A. 1980: Karst Hydrology and Physical Speleology.- Springer-Verlag Berlin Heidelberg New York 1980, 284 p.

DAWKINS, Boyd W. 1874: Cave Hunting, researches on the evidence of caves respecting the early inhabitants of Europe.- London (Macmillan) 455 S., u.a. 50-61.

DAWKINS, Boyd W. 1876: Die Höhlen und die Ureinwohner Europas.-Leipzig u. Heidelberg 1876, 360 S.; u.a. S. 46 ff. 
FINK, M. H. 1984a: Das Karstgebiet beim Hochtor (Hocharngruppe) (Salzburg - Kärnten).Fieldreport, Speldok-Austria KHA-Dok-Archiv, Karst \& cave Dept. Nat. hist. Mus. Vienna.

FINK, M. H. 1984b: Das Karstgebiet beim Hochtor, Hohe Tauern (Salzburg - Kärnten).- Die Höhle (Wien, 1984) 35(3/4): 127-134; Festschrift Hubert TRIMMEL.

GOLDBERGER, J. 1951: Reste abgetragener Höhlen auf dem Hochkönig.- Die Höhle (Wien) 2(1): 9-11.

KLAPPACHER, W. \& KNAPCZYK, H. (Ed.) 1977: Salzburger Höhlenbuch. Band 2.- Salzburg. KLAPPACHER, W. \& KNAPCZYK, H. (Ed.) 1979: Salzburger Höhlenbuch. Band 3.- Salzburg. KLAPPACHER, W. (Ed.) 1996: Salzburger Höhlenbuch. Band 6.-Salzburg.

KRAUS, F. 1894: Höhlenkunde. Wege und Zweck der Erforschung unterirdischer Räume.- Wien 1894, 1-308.

PAVUZA, R.; KLAPPACHER, W. 1996: Karst und Höhlen im Bereich des Nationalparks Hohe Tauern und seiner Umgebung.- Symp. , Forschung im Nationalpark Hohe Tauern, Kaprun 1996“, Kaprun, 2 pages.

\section{"BREZSTROPE" JAME KOT STOPNJA V RAZVOJU JAM NA PRIMERU VZHODNIH APNENIŠKIH ALP NA SALZBURŠKEM IN CENTRALNIH ALP (AVSTRIJA)}

\section{Povzetek}

O pojavu brezstropih jam v devonskih kamninah v Angliji je že zgodaj poročal B. Dawkins (1874). Tudi F. Kraus je s terenskimi raziskavami ugotovil, da je rušenje jamskih stropov prva stopnja v razvoju od normalnih podzemeljskih jam do vrste vrtač z ostanki jam in dalje do sotesk ali dolin s strmimi stenami, iz katerih kasneje nastanejo doline s položnejšimi pobočji. Kot primer starega jamskega sistema navaja Kraus Rakov Škocjan z njegovimi različnimi dolinami in naravnimi mostovi na obeh koncih. Poudarje, da so površinske in podzemeljske oblike vzrok brezstropim jamam. Posebna površinska denudacija tanjša strop in posledica je udor stropa, kot v jami Lončarevec pri Velikem Otoku v okolici Postojne. Strop jame se je stanjšal, nakar so udori odprli "okna” v stropu (Kraus 1894, 73-75, 114). Tako so, kot je zapisal Kraus, jamske zapolnitve na kraškem površju, jarki in doline ostanki jam v tistih predelih, kjer je dolgo časa potekala močna denudacija (1894, 203).

Na alpskem krasu je pogosto prevladujoč proces ledeniška erozija. Bočna in talna erozija glavnih ali stranskih ledeniških jezikov je oblikovala značilne planote in doline. Ponekod se je v strmih pobočjih odprlo veliko jam. Na planotah z blagim naklonom površja pa zaradi površinske erozije nastanejo brezstrope jame.

V Alpah so pleistocenski ledeniki zniževali površje. Zato je površje v strmejših pobočjih prerezalo jamske rove in odprli so se jamski sistemi. Na uravnanem površju pa so bili erodirani jamski stropi. V nekaterih ožjih področjih je danes veliko pretežno kratkih jam - delov nekdanjih jamskih sistemov. Značilne so za "nivo jamskih razvalin" (Höhlenruinen-Nivo). Ime ni ravno pravo, kajti na višjih delih planote so se razvile jame, ki niso "razvaline", ampak so tem le podobne. Veliko ostankov jam, celo sige, je na kraških planotah, kot so Steinernes Meer, Hagengebirge in Tennengebirge, v višinah $2000-2300 \mathrm{~m}$. 
Poseben poudarek je na salzburških Apneniških Alpah, vključno področji Hennenkopf in Rotwandl v pogorju Steinernes Meer, na področju Sondkar v pogorju Tennengebirge in okolici Hochtora v Centralnih Alpah (Visoke Ture). 